\title{
Ambrosia pollen season in selected cities in Poland in 2018
}

\author{
Elżbieta Weryszko-Chmielewska', Anna Woźniak², Krystyna Piotrowska-Weryszko', Agata Konarska', \\ Aneta Sulborska', Małgorzata Puc ${ }^{3,4}$, Katarzyna Dąbrowska-Zapart ${ }^{5}$, Kazimiera Chłopek ${ }^{5}$, Agnieszka Lipiec ${ }^{6}$, \\ Małgorzata Malkiewicz', Dorota Myszkowska ${ }^{8}$, Monika Ziemianin ${ }^{8}$, Beata Żuraw', Barbara Gałusza9, \\ Ewa Kalinowska ${ }^{10}$, Krystian Tywoniuk ${ }^{11}$, Adam Rapiejko ${ }^{10,}{ }^{12}$, Dariusz Jurkiewicz ${ }^{9}$, Grzegorz Siergiejko' ${ }^{13}$, \\ Kornel Szczygielski ${ }^{9}$, Zenon Siergiejk0 ${ }^{14}$, Daniel Kotrych ${ }^{15}$, Piotr Rapiejk0 ${ }^{10,11}$ \\ ${ }^{1}$ Department of Botany, University of Life Sciences in Lublin, Poland \\ ${ }^{2}$ Department of General Ophthalmology, Medical University of Lublin, Poland \\ ${ }^{3}$ Department of Botany and Nature Conservation, Faculty of Biology, University of Szczecin, Poland \\ ${ }^{4}$ Molecular Biology and Biotechnology Centre, Faculty of Biology, University of Szczecin, Poland \\ ${ }^{5}$ Department of Paleontology and Stratigraphy, Faculty of Earth Sciences, University of Silesia, Poland \\ ${ }^{6}$ Department of Prevention of Environmental Hazards and Allergology, Medical University of Warsaw, Poland \\ ${ }^{7}$ Department of Palaeobotany, Institute of Geological Sciences, University of Wroclaw, Poland \\ ${ }^{8}$ Department of Clinical and Environmental Allergology, Jagiellonian University, Medical College \\ ${ }^{9}$ Department of Otolaryngology with Division of Cranio-Maxillo-Facial Surgery in Military Institute of Medicine, \\ Warsaw, Poland \\ ${ }^{10}$ Allergen Research Center, Poland \\ ${ }^{11}$ Department of Otolaryngology, Audiology and Phoniatrics, Children's Hospital of Bydgoszcz \\ 12 Oxford Archaeology Ltd., Oxford, England \\ ${ }^{13}$ Pediatrics, Gastroenterology and Allergology Department, University Children Hospital, \\ Medical University of Bialystok, Poland \\ ${ }^{14}$ Laboratory of Respiratory Diagnostics and Bronchoscopy, Medical University of Bialystok, Poland \\ ${ }^{15}$ Department of Orthopedics and Traumatology, Pomeranian Medical University of Szczecin, Poland
}

\begin{abstract}
:
Ambrosia causes most pollen allergies in North America. After several Ambrosia species were introduced to Europe, an increase in the incidence of allergy to pollen of these plants has been observed in many countries

The aim of this study was to compare Ambrosia pollen seasons in 2018 in 13 cities located in different regions of Poland: Bialystok, Bydgoszcz, Cracow, Drawsko Pomorskie, Lublin, Olsztyn, Opole, Piotrkow Trybunalski, Sosnowiec, Szczecin, Warsaw, Wroclaw and Zielona Gora. The study was conducted by the volumetric method using Burkard or Lanzoni pollen samplers. The pollen season was determined by the $98 \%$ method.

The earliest pollen season start dates (the end of July) were recorded in Zielona Gora, Bydgoszcz, Opole and Szczecin, while the latest ones in Drawsko Pomorskie and Bialystok. The longest pollen seasons occurred in Opole, Szczecin and Zielona Gora (79 days). The highest average daily concentrations of Ambrosia pollen were recorded in Bialystok $\left(129 \mathrm{P} / \mathrm{m}^{3}\right)$ and Lublin $\left(99 \mathrm{P} / \mathrm{m}^{3}\right)$, while the lowest ones in Drawsko Pomorskie and Szczecin (4 and $10 \mathrm{P} / \mathrm{m}^{3}$, respectively). The annual pollen sum reached the highest value in Opole (567 pollen grains) and Zielona Gora (555 pollen grains). It can be concluded from the pattern of Ambrosia pollen seasons at the monitoring sites studied that pollen of this taxon originates not only from Ambrosia locations in Poland but also from long-distance transport.
\end{abstract}

Key words: allergens, pollen concentration, risk of allergy, ragweed, Ambrosia, 2018 
A mbrosia pollen is the most frequent cause of pollen allergy in North America [1]. After five American species of this genus were introduced to Europe, Ambrosia pollen allergens have also become a hazard in many countries of the western, central and eastern parts of this continent [2-6]. Ambrosia artemisiifolia is the most widely distributed both in Western and Eastern Europe [7, 8].

Ragweed flowering and pollen release in Poland last from August, and sometimes already from July, until October [2,9]. Ambrosia artemisiifolia and A. trifida have been found to occur in some regions of Poland, among others in south-west and south-eastern localities [10]. During the 2018 growing season, a new ragweed location was spotted in one of Lublin's districts. To date, it has been shown that in Poland airborne ragweed pollen originates from local stands and from long-distance transport [5].

In many European countries Ambrosia pollen grains are a persistent cause of allergy-associated respiratory diseases [2], and its fragments have been proposed as the trigger for asthma $[4,11]$. Dechamp et al. [12] report that $1-2$ pollen grains in $1 \mathrm{~m}^{3}$ of air may induce slight allergic symptoms. However, Jäger [13] determined that 20 pollen grains $/ \mathrm{m}^{3}$ are the threshold value of Ambrosia pollen concentration causing allergic rhinitis in sensitive individuals. Richter et al. [14] report that $4-5 \%$ of Europe's population are sensitized to ragweed pollen, whereas Rapiejko [2] claims that in areas where ragweed occurs in large numbers about $8-12 \%$ of the population exhibit hypersensitivity to allergens of this pollen.

Aim

The aim of this study was to compare airborne Ambrosia pollen concentrations in 2018 in 13 cities in Poland: Bialystok, Bydgoszcz, Cracow, Drawsko Pomorskie, Sosnowiec, Lublin, Olsztyn, Opole, Piotrkow Trybunalski, Szczecin, Warsaw, Wroclaw and Zielona Gora.

\section{Material and method}

Measurements of Ambrosia pollen concentrations in the atmospheric air of the above-mentioned cities were carried out using volumetric Burkard or Lanzoni samplers, which operated on a continuous basis. Daily $(24 \mathrm{~h})$ pollen counts were counted. The results were expressed as the number of pollen grains in $\mathrm{m}^{3}$ of air per day $\left(\mathrm{P} / \mathrm{m}^{3}\right)$. The pollen season duration was determined by the $98 \%$ method. Start and end pollen season dates, maximum concentration, date of maximum concentration and annual pollen sum were determined. The pollen season pattern was presented in graphs.

When determining the degree of risk of allergy during the Ambrosia pollen season, $5 \mathrm{P} / \mathrm{m}^{3}$ and $20 \mathrm{P} /$ $\mathrm{m}^{3}$ were accepted as the threshold values that may trigger hypersensitivity symptoms, in accordance with the literature data $[13,15]$.

\section{Results and discussion}

In 2018 the Ambrosia pollen season started earliest in Zielona Gora (July 26 $6^{\text {th }}$ ) and latest in Drawsko Pomorskie (August 18 $8^{\text {th }}$ ) (tab. 1, figs 1-6). In Bialystok, Cracow, Sosnowiec and Warsaw, the first pollen grains of this taxon were recorded at the end of the first decade of August (August $8^{\text {th }}-10^{\text {th }}$ ). In 2016, on the other hand, the first Ambrosia pollen grains appeared two weeks later (August $7^{\text {th }}-$ Lublin, Olsztyn) $[16,17]$.

In 2018 attention is drawn to the significant duration of the pollen season of the taxon studied, which was from 46 days (Bialystok) to 79 days (Szczecin, Opole, Zielona Gora), on average 65 days. The $\mathrm{Am}$ brosia pollen season recorded in 2016 at the same monitoring sites was much shorter and reached 46 days on average [16, 17].

The maximum daily concentration of Ambrosia pollen was recorded in eight cities at a similar time, at the beginning of September (September $7^{\text {th }}-8^{\text {th }}$ ), whereas in the several other cities in the last 10 days of August (tab. 1). As an exception, in Wroclaw the peak value occurred as late as September $18^{\text {th }}$. In 2016 the maximum daily concentration of ragweed pollen occurred at the end of the third decade of August almost at all the pollen monitoring sites studied [16, 17].

In 2018 almost all curves representing the $\mathrm{Am}$ brosia pollen season pattern showed the presence of several peaks, similarly as in 2016 [16] and in 2014 [18]. This fact can indicate long-distance pollen transport at different times under favorable weather conditions, which has been demonstrated in several publications [5, 20].

The highest annual total of ragweed pollen grains in 2018 was recorded in Opole (567) and Zielona Gora (555). In 2016 the highest annual total values were also recorded in the same two cities [16].

In 2018 the lowest annual pollen sum was found in Wroclaw, Drawsko Pomorskie and Szczecin (tab. 1). The lowest peak values were recorded in the same cities in the above-mentioned year. The average 
Table 1. Characteristics of Ambrosia pollen season in 2018.

\begin{tabular}{|c|c|c|c|c|c|c|}
\hline \multirow{2}{*}{ Site } & \multirow{2}{*}{$\begin{array}{l}\text { Pollen season period } \\
\text { by the } 98 \% \text { method }\end{array}$} & \multirow{2}{*}{$\begin{array}{l}\text { Season duration / number of days } \\
\text { with concentration above zero }\end{array}$} & \multirow{2}{*}{$\begin{array}{l}\text { Peak value }\left[\mathrm{P} / \mathrm{m}^{3}\right] \\
\text { peak date }\end{array}$} & \multirow{2}{*}{$\begin{array}{c}\text { Annual } \\
\text { pollen sum }\end{array}$} & \multicolumn{2}{|c|}{$\begin{array}{l}\text { Number of days with con- } \\
\text { centration above threshold }\end{array}$} \\
\hline & & & & & $5 \mathrm{P} / \mathrm{m}^{3}$ & $20 \mathrm{P} / \mathrm{m}^{3}$ \\
\hline Bialystok & $10.08-24.09$ & $46 / 30$ & $\begin{array}{l}129 \\
7.09\end{array}$ & 391 & 12 & 4 \\
\hline Bydgoszcz & 28.07-28.09 & $63 / 45$ & $\begin{array}{c}27 \\
8.09\end{array}$ & 256 & 18 & 2 \\
\hline Cracow & $9.08-24.09$ & $47 / 35$ & $\begin{array}{c}19 \\
24.08\end{array}$ & 159 & 11 & 0 \\
\hline $\begin{array}{l}\text { Drawsko } \\
\text { Pomorskie }\end{array}$ & $14.08-30.09$ & $48 / 18$ & $\begin{array}{c}4 \\
30.08\end{array}$ & 33 & 0 & 0 \\
\hline Lublin & $2.08-7.10$ & $67 / 48$ & $\begin{array}{c}99 \\
7.09\end{array}$ & 474 & 17 & 7 \\
\hline Olsztyn & $29.07-13.10$ & $77 / 50$ & $\begin{array}{c}44 \\
7.09\end{array}$ & 252 & 14 & 2 \\
\hline Opole & $28.07-14.10$ & $79 / 71$ & $\begin{array}{c}39 \\
7.09\end{array}$ & 567 & 34 & 7 \\
\hline $\begin{array}{l}\text { Piotrkow } \\
\text { Trybunalski }\end{array}$ & $1.08-10.10$ & $71 / 57$ & $\begin{array}{c}37 \\
7.09\end{array}$ & 396 & 23 & 5 \\
\hline Sosnowiec & $9.08-14.10$ & $67 / 34$ & $\begin{array}{c}74 \\
24.08\end{array}$ & 301 & 13 & 5 \\
\hline Szczecin & $28.07-14.10$ & $79 / 21$ & $\begin{array}{c}10 \\
30.08\end{array}$ & 34 & 1 & 0 \\
\hline Warsaw & $8.08-15.10$ & $69 / 55$ & $\begin{array}{c}56 \\
7.09\end{array}$ & 341 & 20 & 4 \\
\hline Wroclaw & $1.08-20.09$ & $51 / 8$ & $\begin{array}{c}12 \\
18.09\end{array}$ & 19 & 1 & 0 \\
\hline Zielona Gora & $25.07-11.10$ & $79 / 70$ & $\begin{array}{c}58 \\
8.09\end{array}$ & 555 & 36 & 5 \\
\hline
\end{tabular}

Figure 1. Ambrosia pollen count in Bialystok and Lublin in 2018.

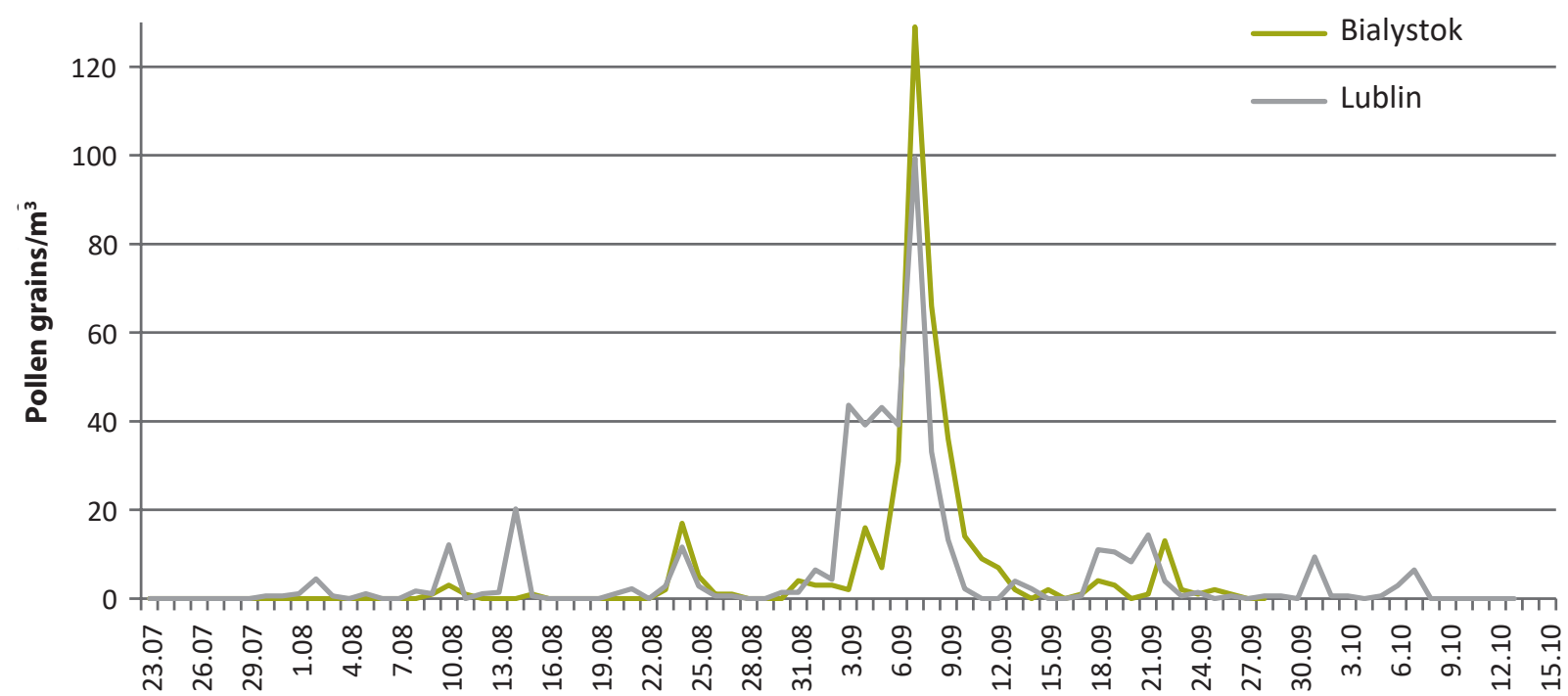




\section{MEDIGAL AEROBIOLOGY}

ORIGINAL PAPER

Figure 2. Ambrosia pollen count in Opole and Piotrkow Trybunalski in 2018.

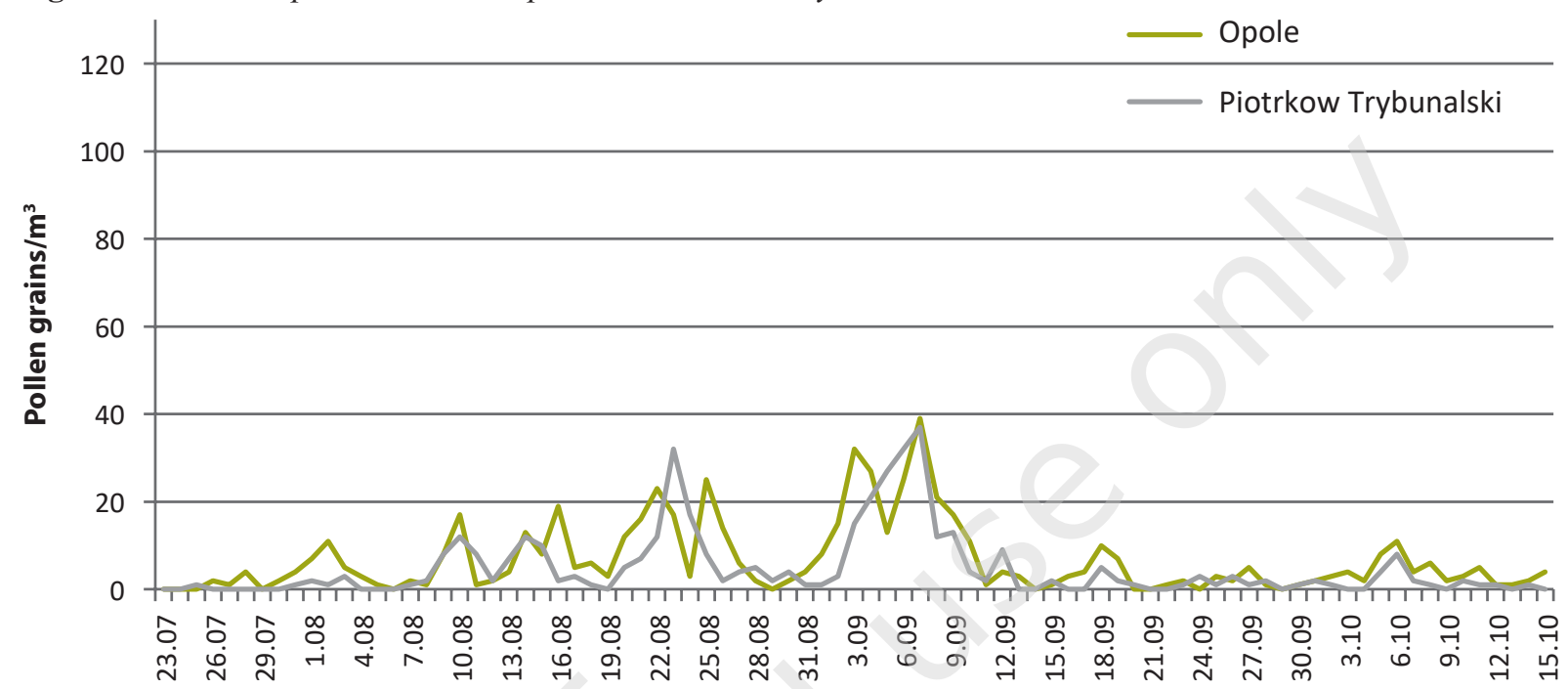

Figure 3. Ambrosia pollen count in Bydgoszcz and Olsztyn in 2018.

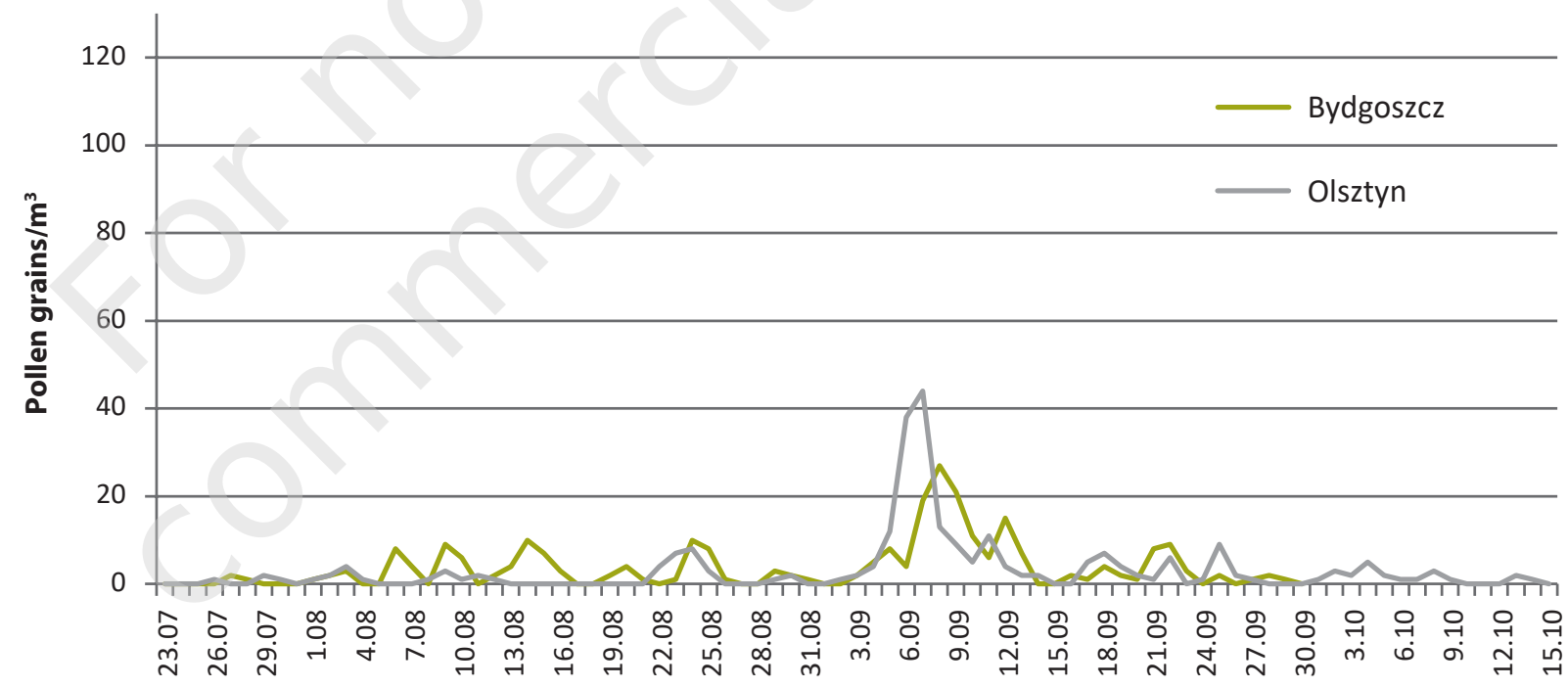

Figure 4. Ambrosia pollen count in Warsaw and Zielona Gora in 2018.

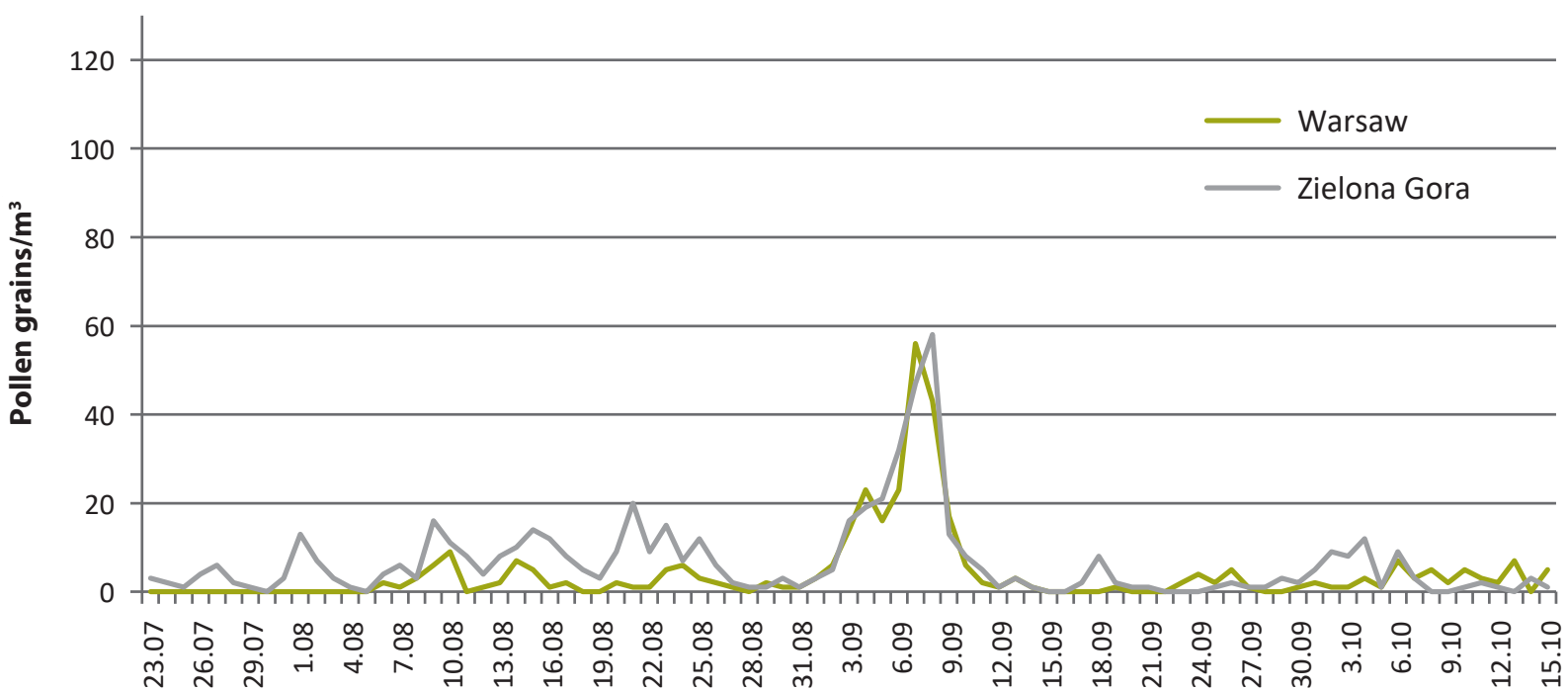


Figure 5. Ambrosia pollen count in Cracow and Sosnowiec in 2018.

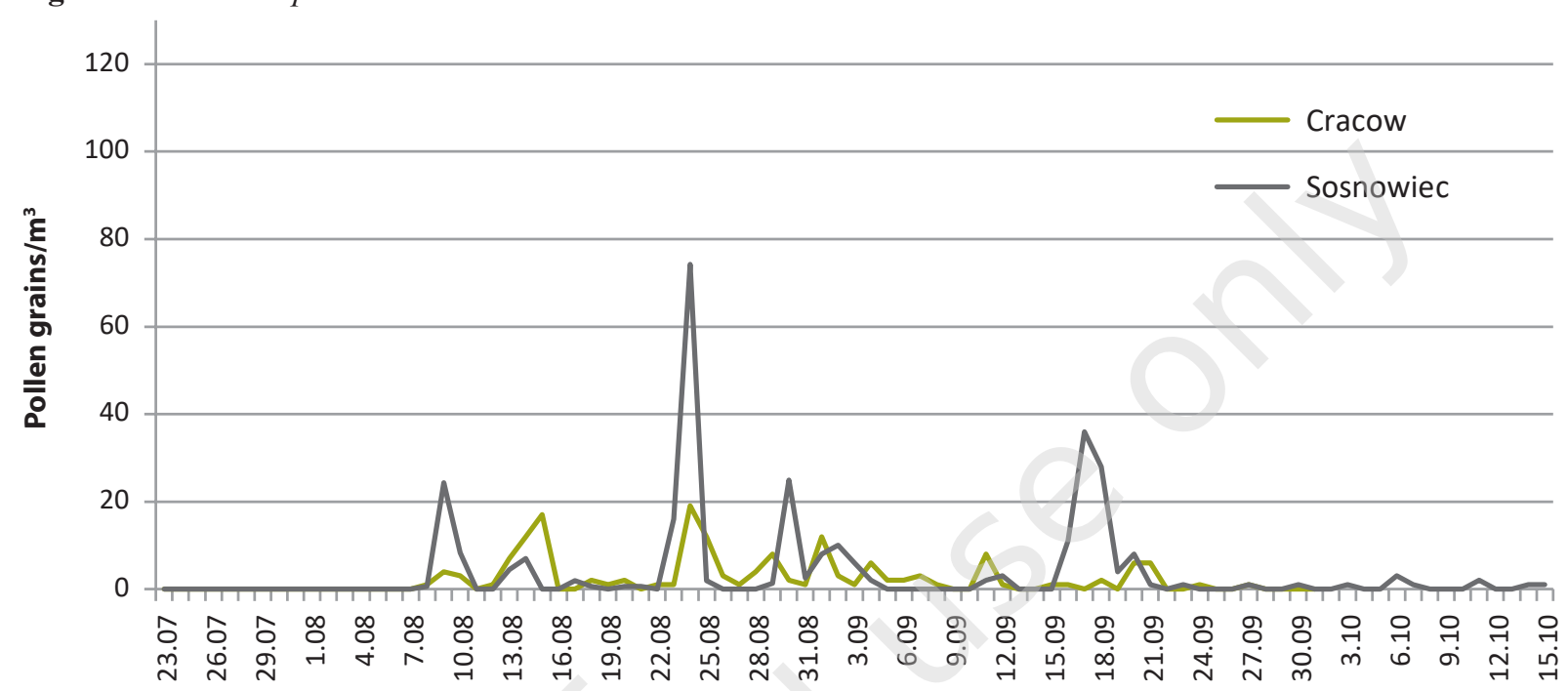

Figure 6. Ambrosia pollen count in Drawsko Pomorskie, Szczecin and Wroclaw in 2018.

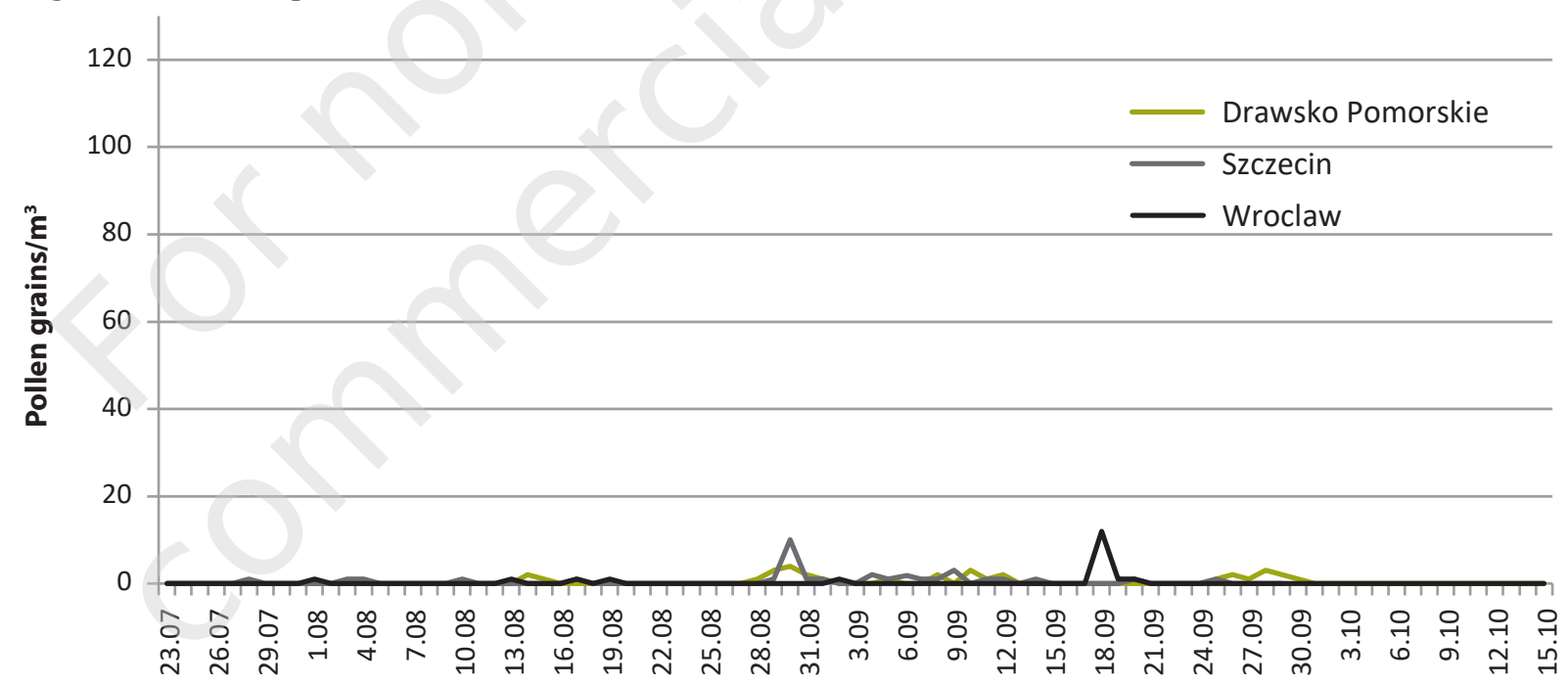

annual pollen sum (291 grains) in 2018 was similar to the average value of this parameter (295 grains) in $2016[16,17]$.

Worth noting is the six-fold increase in the annual pollen sum in Lublin in 2018 compared to its value recorded in 2016 [16], which may be associated with the existence of new Ambrosia locations in this city. During previous years of the study (2001-2005), the highest Ambrosia pollen concentrations were found in Lublin among all pollen monitoring sites existing in Poland [21]. In 2018 Zielona Gora and Opole showed the greatest risk of allergy due to the largest number of days (36 and 34, respectively) with the exceeded threshold value of $5 \mathrm{P} / \mathrm{m}^{3}$, at which allergy symptoms develop in sensitive patients. Concentrations exceeding $20 \mathrm{P} / \mathrm{m}^{3}$ were recorded with the highest frequency in Lublin and Opole (7 days) as well as in Sosnowiec,
Piotrkow Trybunalski and Zielona Gora (5 days). At such concentrations, allergy symptoms occur in most allergy sufferers.

\section{Conclusions}

1. In most of the cities, the Ambrosia pollen season in 2018 had a longer duration than in previous years.

2 . The maximum ragweed pollen concentration in 2018 was recorded in the last 10 days of August or in the first 10 days of September at most of the study sites in Poland.

3. In Opole, Zielona Gora and Lublin, the risk of Ambrosia pollen-induced allergy in patients was highest.

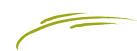




\section{References}

1. Bousquet J, Van Cauwenberge P, Khaltaev N. Allergic rhinitis and its impact on asthma. J Allergy Clin Immunol 2001, 108(5 suppl): 147-334.

2. Rapiejko P. Alergeny pytku roślin. Medical Education, Warszawa 2010.

3. Makra L, Juhász M, Béczi R, Borsos E. The history and impacts of airborne Ambrosia (Asteraceae) pollen in Hungary. Grana 2005, 44: 57-64.

4. Makra L, Amtyasovszky I, Baliant B. Association of allergic asthma emergency room visits with the main biological and chemical air pollutants. Science of the Total Environment 2012, 432: 288-296.

5. Smith M, Skjøth CA, Myszkowska D et al. Long-range transport of Ambrosia pollen to Poland. Agricultural and Forest Meteorology 2008, 148: 1402-1411.

6. Chłopek K, Dąbrowska-Zapart K, Tokarska-Guzik B. An assessment of the Ambrosia L. Pollen threat at a regional scale using the example of the town Sosnowiec (Silesian Uplands Poland). Acta Agrobot 2011, 64(2): 51-62.

7. Jarái-Komlódy M, Juhász M. Ambrosia elatior (L.) in Hungary (1989-1990). Aerobiologia 1993, 9: 75-78.

8. Piotrowska-Weryszko K, Weryszko-Chmielewska E, Voloshchuk $K$ et al. Ragweed (Ambrosia L.) pollen in aeroplankton of Lublin (Poland) and Lviv (Ukraine). Acta Agrobot 2013, 66(3): 3-10.

9. Rutkowski L. Klucz do oznaczania roślin naczyniowych Polski niżowej. PWN, Warszawa 2004.

10. Zając A, Zając M (eds). Atlas rozmieszczenia roślin naczyniowych w Polsce. Pracownia Chorologii Komputerowej Instytutu Botaniki Uniwersytetu Jagiellońskiego, Kraków 2001.

11. Miguel AG, Taylor PE, House J et al. Meteorological influences on respirable fragment release from Chinese elm pollen. Aerosol Sci Technol 2006, 40: 690-696.

12. Dechamp C, Rimet ML, Meon H, Deviller P. Parameters of ragweed pollination in the Lyon's area (France) from 14 years of pollen counts. Aerobiologia 1997, 13: 275-279.

13. Jäger S, Litschauer R. Ragweed (Ambrosia) in Austria. In Ragweed in Europe. $6^{\text {th }}$ International Congress on Aerobiology, 1998, Perugia, Italy.

14. Richter R, Berger UE, Dullinger $S$ et al. Spread of invasive ragweed: climate change, management and how to reduce allergy costs. Journal of Applied Ecology 2013, 50(6): 1422-1430 .

15. Taramarcaz P, Lambelet C, Clot B et al. Ragweed (Ambrosia) progression and it's health risks: will Switzerland resist this invasion? Swiss Med Wkly 2005, 135: 538-548.
16. Piotrowska-Weryszko K, Weryszko-Chmielewska E, Lipiec A et al. Ragweed pollen season in southern Poland in 2016. Alergoprofil 2016, 12(4): 182-185.

17. Puc M, Kotrych D, Rapiejko P et al. Ragweed pollen season in the cities of northern Poland in 2016. Alergoprofil 2016, 12(4): 178-181.

18. Weryszko-Chmielewska E, Piotrowska-Weryszko K, Rapiejko P et al. Analiza stężenia pytku ambrozji w wybranych miastach Polski w 2014 r. Alergoprofil 2014, 10(4): 35-40.

19. Weryszko-Chmielewska E, Piotrowska-Weryszko K, Rapiejko P et al. Analiza stężenia pytku ambrozji w wybranych miastach Polski w 2014 r. Alergoprofil 2014, 10(4): 35-40.

20. Kasprzyk I, Myszkowska D, Grewling Ł et al. The occurrence of Ambrosia pollen in Rzeszów, Kraków and Poznań, Poland: investigation of trends and possible transport of Ambrosia pollen from Ukraine. Int I Biometeorol 2011, 55: 633-644.

21. Weryszko-Chmielewska E (ed). Pytek roślin w aeroplanktonie różnych regionów Polski. Wydawnictwo Akademii Medycznej w Lublinie, Lublin 2006.

ORCID

E. Weryszko-Chmielewska - ID - orcid.org/0000-0001-8410-2757

A. Woźniak - ID - orcid.org/0000-0003-0865-6541

K. Piotrowska-Weryszko - ID - orcid.org/ 0000-0003-3827-3218

A. Konarska - ID - orcid. org/ 0000-0003-2174-7608

A. Sulborska - ID - orcid. org/0000-0002-7720-0719

M. Puc - ID - orcid. org/0000-0001-6734-9352

K. Dąbrowska-Zapart - ID - orcid.org/ 0000-0002-8976-7739

A. Lipiec - ID - orcid.org/0000-0003-3037-232

P. Rapiejko - ID - orcid. org/ 0000-0003-3868-0294

D. Myszkowska - ID - orcid. org/ 0000-0002-1493-3990

M. Ziemianin - ID - orcid.org/ 0000-0003-4568-8710

B. Zuraw - ID - orcid. org/0000-0001-6724-4550

B. Gałusza - ID - orcid.org/ 0000-0002-9594-5108

E. Kalinowska- ID - orcid.org/ 0000-0003-4821-6882

K. Tywoniuk - ID - orcid. org/0000-0002-4610-0002

K. Szczygielski - ID - orcid.org/ 0000-0002-3717-5424

Author's contributions: Weryszko-Chmielewska E: 15\%; Piotrowska-Weryszko K: 15\%; other Authors: $3.3 \%$ each.

Conflict of interests: The authors declare that they have no competing interests.

Financial support: Does not occur.

Ethics: The contents presented in this paper are compatible with the rules the Declaration of Helsinki, EU directives and standardized requirements for medical journals.

Research in Bialystok, Bydgoszzz, Drawsko Pomorskie, Olsztyn, Opole, Piotrkow Trybunalski, Warsaw and Zielona Gora funded by Allergen Research Center Ltd.

Corresponding author:

Prof. Elżbieta Weryszko-Chmielewska, MD, PhD

Department of Botany,

University of Life Sciences in Lublin

20-950 Lublin, Akademicka 15

e-mail: elaweryszko@wp.pl 